\title{
Environmental health compromised by a new epidemic. The case of Uruguay, COVID-19
}

\section{La salud ambiental comprometida por una nueva epidemia. E1 caso de Uruguay, COVID-19}

\begin{abstract}
Mariana Gomez-Camponovo ${ }^{1}$; Marcel Achkar ${ }^{1}$
Suggested citation: Gomez-Camponovo M, Achkar M. Environmental health compromised by a new epidemic the case of Uruguay, COVID-19. Salud UIS. 2020; 52(3): 327-332. doi: http://dx.doi.org/10.18273/revsal.v52n3-2020013 @ (1)

\section{Resumen}

Uruguay se ubica en Sudamérica con una población de 3.286.314 habitantes. El 1,6\% no tiene seguro integral de salud. Los casos detectados de COVID 19 representan el 0,022 \% de la población. Las muertes con relación a los casos detectados representan el 2,6\%. La mortalidad por COVID-19 es de 0,6 por cien mil habitantes. El $14 \%$ de los detectados corresponden a personal de salud. Paulatinamente el país está saliendo del aislamiento social. En el artículo se muestran los casos acumulados, recuperados y activos. Los autores enmarcan las causas de esta zoonosis en un problema de Salud Ambiental y por lo tanto Global, dentro del enfoque "una sola salud". El hombre ha ocupado los suelos de forma extractiva, con urbanización creciente, creciente número de población, diferentes prácticas culturales y condiciones socio-económicas, que han modificado los hábitat naturales. Esto favorece la aparición de zoonosis emergentes y en particular virus con genoma RNA. Si no se atiende a la causalidad del fenómeno, seguiremos asistiendo a desafíos cada vez mayores.
\end{abstract}

Palabras clave: COVID-19; Salud ambiental; Uruguay; Zoonosis; Una salud.

\begin{abstract}
Uruguay is in South America. It has 3,286,314 inhabitants, $1.6 \%$ of which lacks comprehensive health insurance. Detected cases of COVID-19 represent $0.022 \%$ of the population, $2.6 \%$ of which has resulted in death. Mortality from COVID-19 is $0.6 \%$ per 100,000 inhabitants, and health workers represent $14 \%$ of detected cases. The country is slowly coming out of intensified social distancing. This article reports on accumulated, recovered, and active cases. The authors also frame the causes of this zoonosis in terms of an environmental health problem, and thus a global health problem, requiring a "one health" approach. Human activity has changed natural habitats as a result of extraction activities, increased urbanization, growing populations, different cultural practices, and socioeconomic conditions. This contributes to the emergence of zoonoses, particularly RNA viruses. If the cause of this phenomenon is not addressed, we will continue facing increasing challenges.
\end{abstract}

Keywords: COVID-19; Environmental health; Uruguay; Zoonoses; One health.

1. Universidad de la República. Paysandú, Uruguay.

Correspondence: Mariana Gomez-Camponovo. Address: Social Medicine Unit, CENUR Litoral Norte Universidad de la Republica, Florida 1065, Paysandu-Uruguay Phone number:+59 847226733. Email: mgomez@cup.edu.uy 


\section{Introduction}

Uruguay is located in South America. It measures $176,215 \mathrm{~km}^{2}$. According to the latest census, it has $3,286,314$ inhabitants, $94.7 \%$ of which lives in urban centers. Overall density is 18.6 inhabitants $/ \mathrm{km}^{2}$, and the literacy rate is $98.5 \%{ }^{1}$. Natural population growth is $0.19 \%$ and life expectancy is 81.2 years for women and 73.7 years for men ${ }^{2}$. The birth rate is 13.4 per 1,000 inhabitants and mortality is 9.5 per 1,000 . The human development index is $0.790^{3}$ and the unemployment rate is $8.4 \%$. The gross domestic product is $\$ 59,918$ million $^{5}$, with significant weight on agricultural exports. Administratively, the country is divided into 19 departments.

Description of the problem: A new government took office on March 1 of this year, and the first cases of COVID-19 were detected on March 13.That is when the government began taking certain steps to discourage large numbers of people from gathering in places such as businesses with large spaces, large sporting events, movies, theaters, and cultural events. The government's March report also mentioned polyclinics, and proceeded to close them. In-person classes were also suspended at all educational levels, including universities.

Another social measure for mitigating the situation was short-term aid for those with formal employment, issued by the State Department of Social Security. These measures were relaxed in order to benefit the largest number of people, thereby encouraging them to stay home.

Several social programs were also expanded, including food programs, while civil society primarily took up organizing the distribution of food baskets and donated cooked food ("ollas populares"), which are more plentiful in places where the population is better organized.

In parallel, the health system began the phase of assessing its available infrastructure and material and human resources across the country.

With regard to health insurance, $1.6 \%$ of the population lacks public or private comprehensive coverage ${ }^{6}$.

The government quickly contacted a group of renowned scientists to voluntarily serve as consultants.

Since Uruguay is a small country, the issue of scale made it difficult to obtain the tests needed for the diagnostic stage. As a result, the National Research Agency, through public appeals, has financed projects involving researchers from the University of the Republic and the Pasteur Institute ${ }^{7}$, in order to contribute to the country's installed capacity with highly trained and qualified human capital. These actions have notably increased the diagnostic testing capacity without depending on international providers.

In early May, in a matter of days, it was possible to administer over 1,000 tests daily. This was one of the goals that the system determined to be necessary for better understanding community transmission and which interrelated groups of people were being impacted the most.

With regard to health system resources, most of the intensive care resources are in metropolitan areas, where over $60 \%$ of the country's population resides. While north of the Negro River, both human resources and installed capacity are the scarcest, especially in the public sector.

\section{Surveillance System}

Regarding the temporal distribution of the cases that have been reported by the epidemiological surveillance system, Figure 1 presents the frequency of accumulated, recovered, and active cases between March 13 and May 13. While this represents two months, we can say that recovered cases increased while the curve of active cases did not greatly increase during this period.

As of May 13, there were 719 total accumulated cases, considered an indicator of health since this represented $0.022 \%$ of the population.

There have been 19 total deaths to-date, representing $2.6 \%$ of known cases of infection.

Of the detected cases of infection, 14\% corresponds to health workers, with 1 death. Eighty percent of the reported cases of health workers occurred within one month of detecting the first cases.

A total of 30,209 tests has been performed to-date, representing 9.2 per 1,000 inhabitants.

A comparison with other countries in the region of COVID-19 mortality rates (with the same end date as the Uruguay data, May 13), per 100,000 inhabitants, shows: 6.2 in Brazil, 2.2 in Chile, 0.8 in Argentina, 0.6 in Uruguay, and 0.17 in Paraguay. 


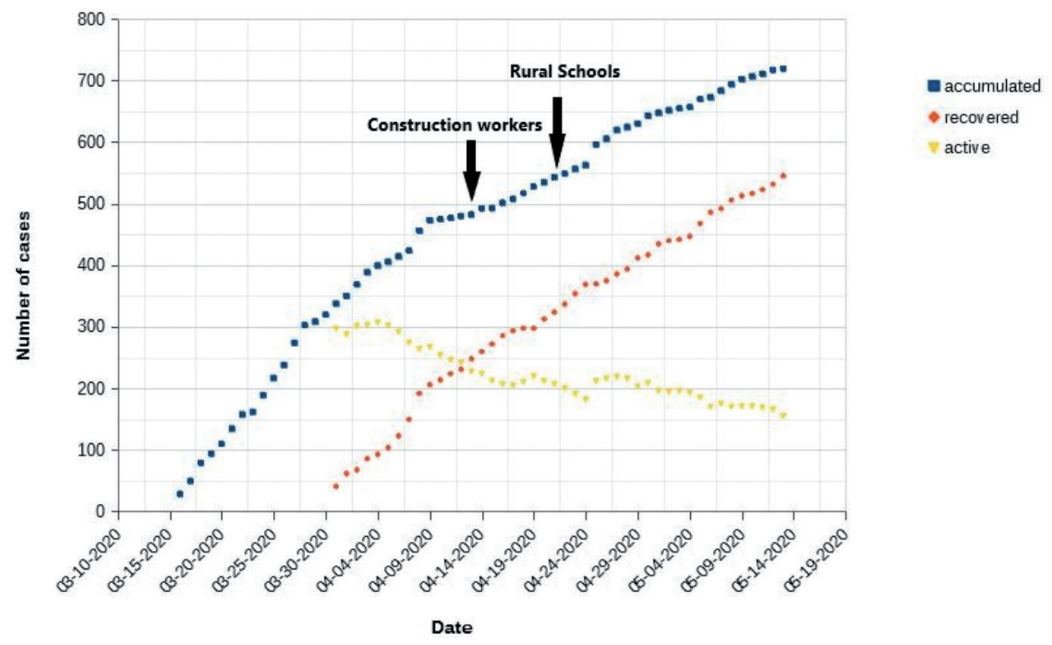

Figure 1. Accumulated, recovered and active cases of COVID 19, Uruguay, 2020.

Cases have been reported in 15 of the 19 departments (Figure 2).

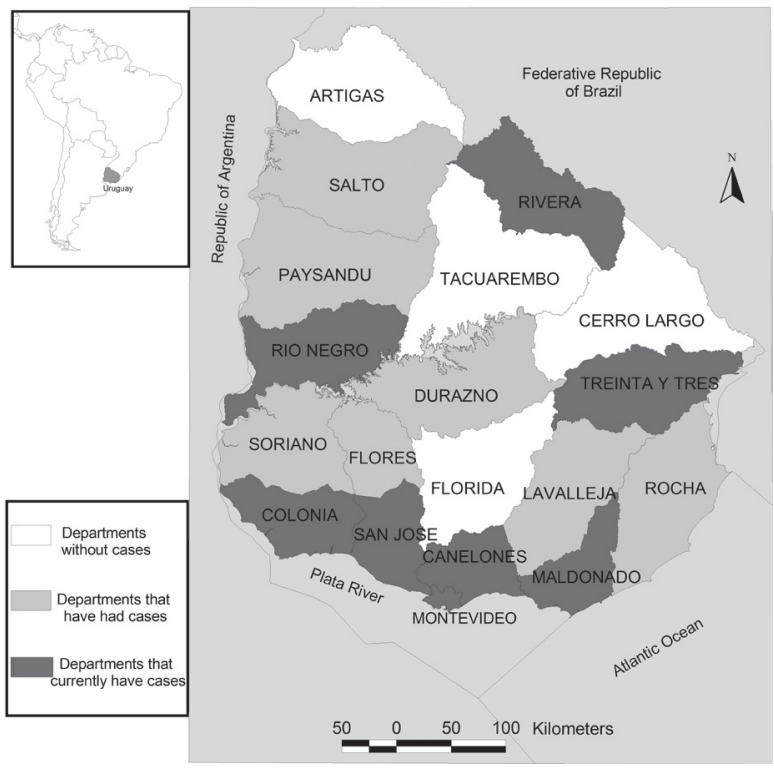

Figure 2. Notified cases in the departments Uruguay, MarchMay, 2020.

\section{Lifting of Social Distancing}

The first two steps taken to begin lifting social distancing were restarting construction work on April 13 (45,000 workers) and opening rural schools on April 22 (optional attendance), except for the most populated departments with a larger number of cases (Canelones and Montevideo). Currently, few students are attending.

As seen in Figure 1, the curve did not change in spite of these two events, which also resulted in the simultaneous increase in related activities.

\section{Primary Health Care}

One month after the first notifications, primary care physicians expressed concern that checkups for people with chronic illnesses were being neglected, and because primary care is the level of care that should be provided to the majority of those infected, but many of those centers were closed.

\section{A new challenge for environmental health}

Just as this pandemic presents us with a planetary problem, the authors believe that we are facing this problem due to how environmental conditions are managed, and that this will continue.

The first part of this text described COVID-19 cases during the first two months and the impact on Uruguay, as well as early measures to mitigate the problem. Given the importance of the problem and the strategy that has been used in the country, in this article, the authors want to highlight what they consider to be the true causes of this problem, in order to understand the material bases underlying it. Without this recognition, we will not have elements for acting on the causes, but will only be able to lessen the consequences.

We are witnessing one more manifestation of how anthropocentrism compromises the environmental health of the planet. In reality, we share both a single ecosystem ${ }^{8}$ and "one health".

Many conditions may be contributing to the emergence of a new virus. Those that are usually found are population density and particular practices by those populations. $^{9}$ There is also a growing trend in the emergence of RNA viruses ${ }^{9}$. 
Zoonoses have been increasing due to intensive human land use practices, which along with growing urbanization processes are slowly blurring the interface between humans and domestic and wild animals ${ }^{10,11}$. Host habitats have been recognized as domestic, peridomestic, and sylvatic ${ }^{11}$.

Human exposure is less common in sylvatic habitats, but this is changing with environmental degradation and human intrusion ${ }^{11}$.

Based on these considerations, the source of this new virus, as well as earlier ones, has progressively been identified as intensified extraction activity, with their significant transformations of wild ecosystems and the global environment ${ }^{12,13}$. Along with these modifications of environmental systems, urbanization models with large concentrations of populations in limited spaces have been increasing and expanding ${ }^{14}$. These processes produce ongoing re-territorialization of the global population, with different local manifestations ${ }^{15}$. In brief: farming populations move to cities, upper and upper-middle classes move to new urban zones on the outskirts of cities, working populations concentrate in highly dense urban population zones, and populations with scarce resources live under precarious urban conditions in areas where the environmental quality is not adequate for human living ${ }^{16}$.

These are complex phenomena, and, identifying the determinants of emerging pathogens requires an inter-disciplinary approach —biological, ecological, economic, and social ${ }^{17}$.

Cultural elements are relevant to the appearance of zoonoses in peridomestic environments ${ }^{11}$. Changes in ecosystems have been found to create conditions for sylvatic species to be introduced into peridomestic environments, facilitating the spread of these diseases. This spread is also related with a lack of socio-economic resources, poor-quality water for consumption, inadequate housing, and particular conditions such as floods ${ }^{11}$. It is important to consider all of these factors, since they contribute to effective contact between human populations and fauna species that generally have not interacted, leading to the development of zoonosis ${ }^{11}$.

In this way, intermediate hosts appear among humans ${ }^{18}$, transmitting the infectious agent, as is known to happen with civets that transmit SARS-CoV to humans ${ }^{19}$, while bats are recognized as the source of this spread ${ }^{19}$.
The conservation of ecosystem biodiversity is a natural mechanism for preventing effective contact ${ }^{11}$.

Nevertheless, at the global scale, the discussion has centered more on the effects of the pandemic and wagering on an effective control mechanism, giving no priority to the analysis of the causes of the emergence of new zoonoses and the possibility of reversing those causes. In that regard, reports over recent months suggest that the structure of health systems and the possibility of implementing measures for their functioning seem to be the key to establishing effective measures for controlling the emergence and expansion of the virus among populations in highly dense regions.

\section{Conclusions}

Detected cases represent $0.022 \%$ of the country's population, and deaths represent $2.6 \%$ of detected cases.

Since it is accepted ${ }^{20}$ that the number of asymptomatic or paucisymptomatic cases is important, mortality from COVID-19 is compared with other countries in the region, finding Uruguay to be lower than Brazil , Chile and Argentina, with Paraguay having the best indicator.

In Uruguay, health care workers represent $14 \%$ of detected cases, while $4.4 \%$ was reported in China ${ }^{21}$. That report indicates that new cases no longer occurred once the health care workers were advised of the situation and adopted adequate protection measure ${ }^{21}$. The same may be happening in Uruguay, since $80 \%$ corresponds to the first month in which the first cases were detected.

The multiple dimensions of the problem need to be understood, including the epidemiology, and also ecology and the multiple levels at which interactions between living beings develop, and how they relate with each other ${ }^{11}$.

Though much less frequent, there are those who still argue, even today, that a strategy could be to eradicate some species that is carrying the infectious agent. However, illnesses should actually be understood as natural processes. With the elimination strategy, new species could appear along with other pathogens or parasites that fill the empty niches that would be left behind ${ }^{11}$.

Public health should take action and facilitate control and management strategies based on the framework of "one health" and with knowledge about ecology and epidemiology ${ }^{11}$. 
Increase mobility of human populations, accelerated and unorganized settlements across the world, overexploitation of natural resources, and decreased wildlife areas are factors that are going to continue to contribute to the emergence of diverse diseases ${ }^{11}$. This requires collaborative, interdisciplinary, and interinstitutional action. Furthermore, a perspective that enables recognizing this as an environmental health problem, related with global environmental change, would discourage point solutions created in each region by whomever governs them. Preventing new epidemics with these characteristics requires working on broad-based strategies that support environmental stewardship, with the understanding that the key is knowing that what is to be preserved is "one health."

If we fail to go beyond symptoms and do not act on the causes, this will become another one of the situations to which we will have to become accustomed.

\section{References}

1. National Institute of Statistic (INE, Spanish acronym) Resultados del Censo de Población 2011: población, crecimiento y estructura por sexo y edad, 2012. https://web.archive. org/web/20190115212157/http://ine.gub.uy/ documents/10181/35289/analisispais.pdf/cc0282ef2011-4ed8-a3ff-32372d31e690

2. World Health Organization, Health Topic, Country: Uruguay. 2016. https://www.who.int/countries/ury/es/

3. United Nations Development Program (UNDP), 2014. Rapport sur le développement humain 2014. http://hdr.undp.org/sites/default/files/hdr14report-fr.pdf

4. National Institute of Statistic(INE, Spanishacronym). Boletín Técnico Actividad, Empleo y Desempleo, 2019. www.ine.gub.uy/documents/10181/30865/ $\mathrm{ECH}+$ Empleo+Enero+2020/43ad8dd9-baff4af8-8589-881

5. Central Bank of Uruguay (BCU, Spanish acronym). Estadísticas y Estudios. Nota Metodológica - Marzo 2020, 2020. https://www.bcu.gub.uy/Estadisticas-eIndicadores/Paginas/Presentacion\%20Cuentas\%20 Nacionales.aspx

6. National Ministery of Health (MSP, Spanish acronym) Informes. Informe Cobertura poblacional del SNIS según prestador 2018. https://www.gub. uy/ministerio-salud-publica/tematica/coberturapoblacional

7. Instituto Pasteur de Montevideo. Udelar e IP Montevideo presentaron kit de diagnóstico
COVID-19, 2020. http://pasteur.uy/novedades/ udelar-e-ip-montevideo-presentaron-kit-dediagnostico-covid-19/

8. Rabinowitz P, Conti L. Links among human health, animal health, and ecosystem health. Annu Rev Public Health. 2013; 34: 189-204. doi: 10.1146/ annurev-publhealth-031912-114426.

9. Dennehy JJ. Evolutionary ecology of virus emergence. Ann. NY Acad Sci. 2017; 1389(1): 124146. doi: 10.1111/nyas. 13304

10. Estrada-Peña A, Ostfeld RS, Townsend Peterson A, Poulin R, de la Fuente J. Effects of environmental change on zoonotic disease risk: an ecological primer. Trends in Parasitol. 2014; 30(4): 205-214. doi: $10.1016 /$ j.pt.2014.02.003

11. McMahon J, Morand S, Gray JS. Ecosystem change and zoonoses in the Anthropocene. Zoonoses Public Health. 2018; 65(7): 755-765. doi: 10.1111/ zph.12489

12. Altieri M, Nicholls CI. La agroecología en tiempos del COVID-19. Consejo Latinoamericano de Ciencias Sociales (CLACSO). 2020. https:// www.clacso.org/la-agroecologia-en-tiempos-delcovid-19/

13. Wallace R. Big farms make big flu: dispatches on influenza disease, agribusiness, and the nature of science. Monthly Review. NY, 2016.

14. Linares S, Di Nucci J,Velázquez G. Cambios en el sistema urbano. En: Velázques G, coordinador. Geografía y calidad de vida en Argentina. Un análisis regional y departamental 2010. Tandil. CIG-UNCPBA. 2016; 67-81.

15. Chanampa ME, Lorda MA. Informal settlements and urban regularization. Production of territorialities in tension. Bitácora Urbano Territorial. 2020; 30(1): 141-150. doi: http://dx.doi.org/10.15446/bitacora. v30n1.69896

16. Beuf A. Centralidad y policentralidad urbanas. Espiral Rev Geograf Ciencias Sociales. 2020; 1(2): 131-155.

17. Jones BA, Grace D, Kock R, Alonso S, Rushton J, Said MY, et al. Zoonosis emergence linked to agricultural intensification and environmental change. Proc Natl Acad Sci USA. 2013; 110(21): 8399-8404. doi: 10.1073/pnas. 1208059110

18. Abdullahi IN, Emeribe AU, Mustapha JO, Fasogbon SA, Ofor IB, Opeyemi IS, et al. Exploring the genetics, ecology of SARS-CoV-2 and climatic factors as possible control strategies against COVID-19. Infez Med. 2020; Ahead of Print 28(2): 166-173. 
19. Plowright RK, Eby P, Hudson PJ, Smith IL, Westcott D, Bryden WL, et al. Ecological dynamics of emerging bat virus spillover. Proc R Soc B. 2015. doi: http://dx.doi.org/10.1098/rspb.2014.2124

20. Gostic K, Gomez AC, Mummah RO, Kucharski AJ, Lloyd-Smith JO. Estimated effectiveness of symptom and risk screening to prevent the spread of COVID-19. Elife. 2020; 9: e55570. doi:10.7554/ eLife. 55570

21. Zhan M, Qin Y, Xue X, Zhu S. Death from Covid-19 of 23 Health Care Workers in China. N Engl J Med. 2020; 382(23): 2267-2268. doi: 10.1056/ NEJMc2005696 